\title{
High Hemoglobin Level
}

National Cancer Institute

\section{Source}

National Cancer Institute. High Hemoglobin Level. NCI Thesaurus. Code C162105.

A higher than average level of hemog lobin in a sample. 